\title{
NOTE
}

\section{Spatial distribution of methane in the Lake Biwa sediments and its carbon isotopic compositions}

\author{
Jun MURASE $^{1 *}$ and AtSUKo SUGIMOTO ${ }^{2}$ \\ ${ }^{1}$ School of Environmental Science, The University of Shiga Prefecture, Hikone, Shiga 522-8533, Japan \\ ${ }^{2}$ Center for Ecological Research, Kyoto University, Otsu, Shiga 520-2113, Japan
}

(Received March 29, 2001; Accepted June 25, 2001)

\begin{abstract}
The spatial variation of methane contents and its stable carbon isotopic composition of sediments from a mesotrophic lake (Lake Biwa) were determined. Methane concentrations in the sediments $(0-10 \mathrm{~cm})$, ranging from 0.04 to $2.41 \mu \mathrm{mol} \mathrm{ml}^{-1}$, were weakly correlated with the amounts of organic carbon in the surface sediments $(0-2 \mathrm{~cm})$, but were poorly correlated with the nitrogen isotopic composition of the bulk sediments used as an indicator of the origin of the organic matter (autochthonous vs. allochthonous). The carbon isotopic composition of methane ranged from -61 to $-80 \%$ and exhibited positive correlation with methane concentration and the carbon isotopic composition of total carbonate $\left(\sum \mathrm{CO}_{2}\right)$. The apparent fractionation factor $\left(\alpha \mathrm{cCH}_{4}-\mathrm{CO}_{2}\right)$ between methane and $\Sigma \mathrm{CO}_{2}$ was in the range between 1.07 and 1.085, which were rather high compared to previously reported values in freshwater sediments. The results suggested that major parts of methane were produced via $\mathrm{CO}_{2}-\mathrm{H}_{2}$ in the Lake Biwa sediments.
\end{abstract}

\section{INTRODUCTION}

Methanogenesis is the most important terminal process in the anaerobic metabolism of freshwater sediments. Methane production is mediated by a complex microbial community and influenced by several environmental factors. For example, temperature strongly influences both the rate and pathways of methane production (Zeikus and Winfrey, 1976; Schulz and Conrad, 1996; Schulz et al., 1997). The amount of available organic matters is another controlling factor for methane production in lake sediments. Comparative studies on methane production have been conducted in the sediments of lakes with different water temperatures and productivity (Casper, 1996; den Heyer and Kalff, 1998).
Water temperature, sedimentation rate, and composition of organic materials deposited are different not only among lakes but also within a lake, especially when the lake is large. The littoral sediment is characterized by relatively high temperature and load of organic matters from terrestrial origins, while the profundal sediment is constantly low in temperature and rich in organic matters derived from the primary production inside a lake (Yoshioka et al., 1988; Murase and Sakamoto, 2000). Such heterogeneous distribution of organic matters and temperature conditions can lead to a spatial variation in methane production within a lake (den Heyer and Kalff, 1998). The purpose of our study is to investigate the spatial distribution of methane in sediments within Lake Biwa, a largest mesotrophic lake in Japan. The

*Corresponding author (e-mail: murase@agr.nagoya-u.ac.jp)

*Present address: Graduate School of Bioagricultural Sciences, Nagoya University, Nagoya, Aichi 464-8601, Japan 
stable carbon isotopic compositions of methane and carbon dioxide were measured to discern the methane production pathways. The relationships between methane distribution and some environmental factors were discussed.

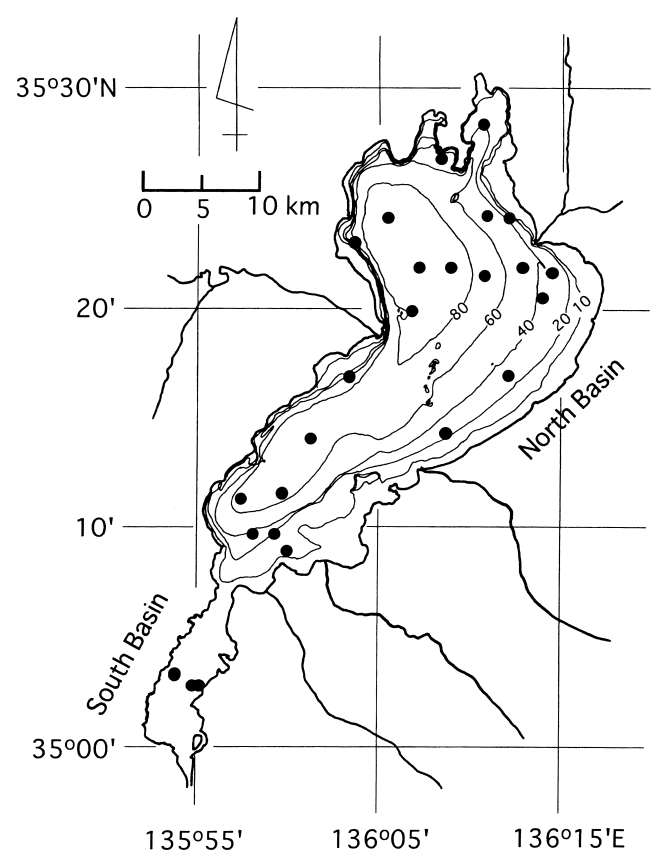

Fig. 1. Map of Lake Biwa. Solid circles indicate the localities of core samples.

\section{Materials ANd Methods}

The lake sediments were collected from July 1997 to July 1999 in Lake Biwa (Fig. 1) using a gravity corer (i.d. of $5 \mathrm{~cm}$ ). The surface portion $(0-10 \mathrm{~cm})$ was subsampled from the core sample with a 50-ml truncated glass syringe. The syringe was plugged with a butyl rubber stopper and stored in an icebox until gas analysis that was carried out within 2-3 hours after sampling.

Methane and total inorganic carbon $\left(\mathrm{SCO}_{2}\right)$ in the syringe were extracted in a He-purged glass container (300 ml in capacity) to which $60 \mathrm{ml}$ of $1 \mathrm{~N} \mathrm{H}_{2} \mathrm{SO}_{4}$ and $10 \mathrm{~g} \mathrm{l}^{-1} \mathrm{CuSO}_{4}$ solution had been added (Fig. 2). Methane and $\mathrm{CO}_{2}$ released to the gas phase were analyzed by a gas chromatograph equipped with a flame ionization detector and a thermal conductivity detector (Shimadzu GC$14 \mathrm{~B})$. The amounts of methane and $\sum \mathrm{CO}_{2}$ in sediment samples were calculated from their concentrations in the gas phase using the Bunsen adsorption coefficient. The carbon isotopic compositions of methane and $\sum \mathrm{CO}_{2}$ were determined by a GC/GC/C/IRMS system (Sugimoto, 1996). The stable carbon isotopic compositions are expressed in per mil deviation from a standard as follows:

$$
\delta^{13} \mathrm{C}(\% o)=\left(\mathrm{R}_{\text {sample }} / \mathrm{R}_{\text {standard }}-1\right) \times 1,000,
$$
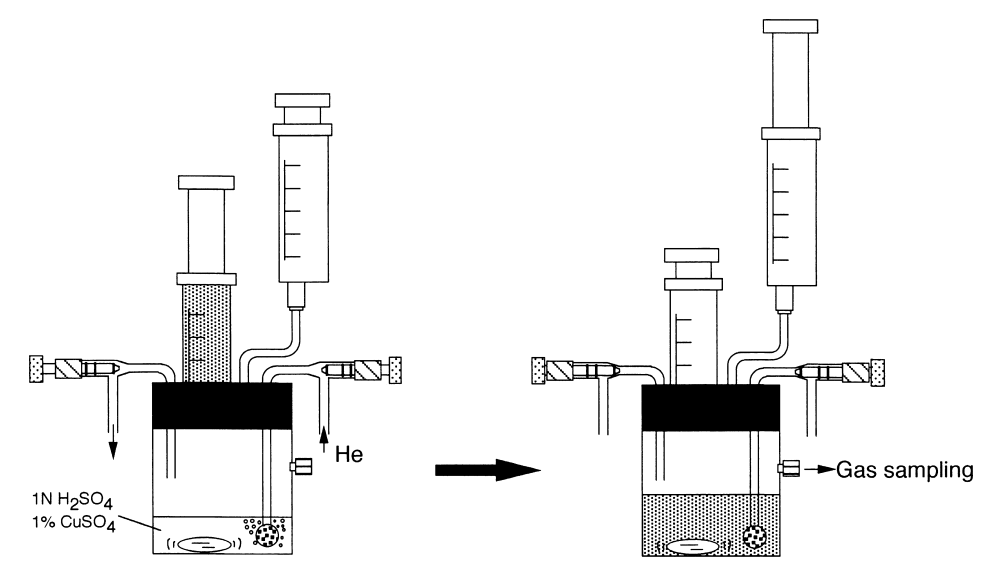

Fig. 2. A schematic presentation of gas recovery. The container was purged with helium gas (>99.9999\%) for 10 min to remove trace amounts of methane and $\mathrm{CO}_{2}$ in the gas and liquid phases before injection of a sediment sample. After injection of the sample, the slurry was well stirred for 40 min to extract methane and $\mathrm{CO}_{2}$, followed by gas sampling from the side port of the container. 
where R denotes ${ }^{13} \mathrm{C} /{ }^{12} \mathrm{C}$. Standard material is PD Belemnite. Carbon dioxide, the isotope composition of which had been previously determined, was used as a working standard.

\section{RESULTS AND DISCUSSION}

Methane contents in sediment ranged from 0.04 to $2.41 \mu \mathrm{mol} \mathrm{ml}{ }^{-1}$ of sediment. The water depth of the sampling sites, which is used as a surrogate variable for temperature (den Heyer and Kalff, 1998), is poorly correlated with the methane concentration (Fig. 3(a)). Methane concentrations exhibit a weak correlation with the total carbon content in surface sediments $(0-2 \mathrm{~cm}$ ) (Fig. $3(\mathrm{c})$ ). The total carbon contents of the same samples were taken from Murase and Sakamoto (2000).

Nitrogen isotopic composition of sediment can be used as an indicator for the origin of the deposited organic matter. Autochthonous organic matter is characterized by high $\delta^{15} \mathrm{~N}$ values, while allochthonous organic matter has relatively low $\delta^{15} \mathrm{~N}$ values (Yoshioka et al., 1988; Murase and Sakamoto, 2000). Autochthonous organic matter is decomposed more easily than allochthonous organic matter (Yoshioka et al., 1989) and contributes to the development of anoxia and methanogenesis in sediment. It is thus expected that high methane concentration correlated with high $\delta^{15} \mathrm{~N}$ values. However, the correlation of $\delta^{15} \mathrm{~N}$ values with methane concentration was unexpectedly weak (Fig. 3(d)). These results suggested that the amounts of deposited organic matter may be a more predominant factor over the origin of organic matter in controlling methanogenesis in sediment.

The regression of methane with carbon content still left a large amount of residuals, suggesting the existence of other variables. Escape of produced methane from the sediment due to diffusion or compaction of the sediment might be possible. Another possibility for the residuals may be heterogeneous distribution of oxidants in sediments. It is suggested that the fraction of or-
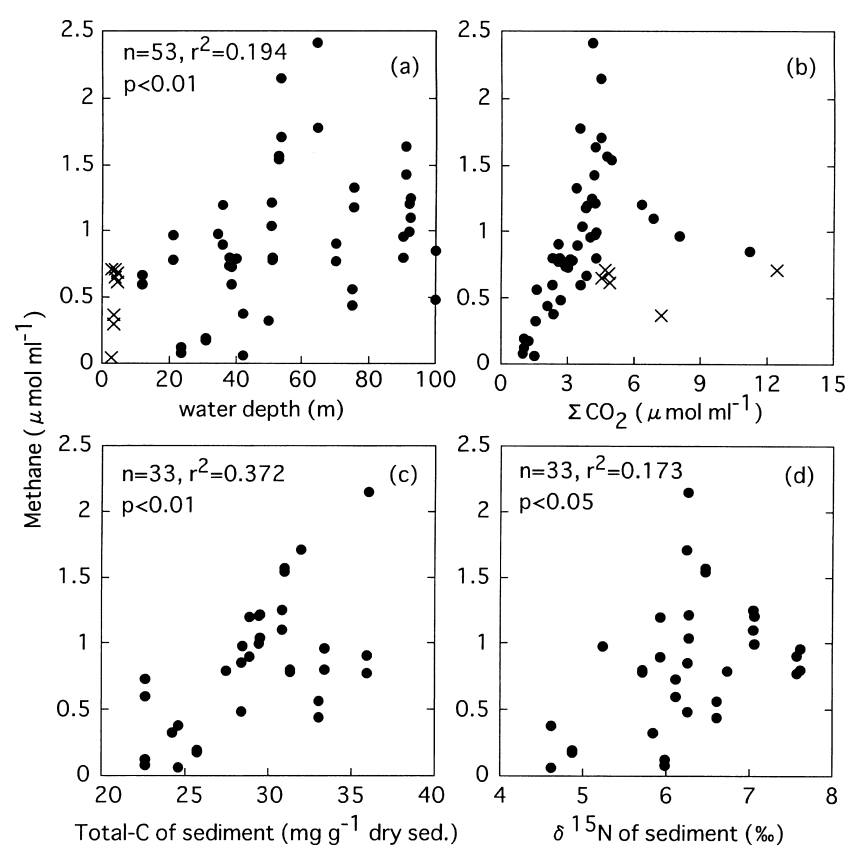

Fig. 3. Methane content vs. (a) water depth, (b) $\Sigma \mathrm{CO}_{2}$, (c) total carbon content, and (d) $\delta^{15} \mathrm{~N}$ value of the sediments samples from the north $(\bullet)$ and south $(\times)$ basins of Lake Biwa. The total carbon content and $\delta^{15} N$ value of the sediment for the surface portion $(0-2 \mathrm{~cm})$ of the same samples were taken from a literature (Murase and Sakamoto, 2000). 
ganic carbon metabolized to methane is controlled not only by the deposition rate of labile organic carbon but also by the availability of oxidants such as $\mathrm{O}_{2}, \mathrm{NO}_{3}{ }^{-}, \mathrm{Fe}(\mathrm{III}), \mathrm{Mn}(\mathrm{IV})$, and $\mathrm{SO}_{4}{ }^{2-}$. Spatial heterogeneity of the oxidants might influence methanogenesis. With a few exceptions, sediments from the south basin showed higher $\sum \mathrm{CO}_{2}$ to methane ratios (Fig. 3(b)) than those from the north basin, suggesting more oxidative degradation of organic matter in the south basin. Oxygen is likely supplied continuously to the sediments of the south basin due to shallow water depth $(<5 \mathrm{~m})$.

Figure 4 illustrates the relationships between $\delta^{13} \mathrm{C}_{\mathrm{CH}_{4}}$ vs. methane and $\delta^{13} \mathrm{C}_{\mathrm{CH}_{4}}$ vs. $\delta^{13} \mathrm{C}_{\mathrm{CO}_{2}}$. Excluding one datum from the south basin $\left(-60.7 \%\right.$ o), $\delta^{13} \mathrm{C}_{\mathrm{CH}_{4}}$ values ranged from -70.9 to $-79.7 \%$, and $\delta^{13} \mathrm{C}_{\mathrm{CO}_{2}}$ values were within the range from -8.8 to $6.5 \%$. The ranges were wider compared to $\delta^{13} \mathrm{C}$ values of the bulk sediment ranging from -25.6 to $-24.6 \%$ (Murase and Sakamoto, 2000). These values of $\delta^{13} \mathrm{C}_{\mathrm{CH}_{4}}$ and $\delta^{13} \mathrm{C}_{\mathrm{CO}_{2}}$ were lower and higher than most of those previously reported values for freshwater sediments and were similar to those observed in marine sediments and peat bogs (Whiticar et al., 1986; Lansdown et al., 1992). The $\delta^{13} \mathrm{C}_{\mathrm{CH}_{4}}$ value exhibited a positive correlation with methane content and the $\delta^{13} \mathrm{C}_{\mathrm{CO}_{2}}$ value (Fig. 4). The apparent carbon isotopic fractionations $\left(\alpha \mathrm{CO}_{2}-\mathrm{CH}_{4}\right)$ be- tween methane and $\Sigma \mathrm{CO}_{2}$ ranged from 1.064 to 1.084 , which were also similar for marine sediments but not for freshwater sediments (Whiticar et al., 1986). Two primary metabolic pathways are generally recognized for biological methanogenesis: fermentation of acetate and reduction of carbon dioxide, and the low $\delta^{13} \mathrm{C}_{\mathrm{CH}_{4}}$ values and high $\alpha \mathrm{cCO}_{2}-\mathrm{CH}_{4}$ values both suggested that methane in the sediments of Lake Biwa is predominantly produced via $\mathrm{CO}_{2}$ reduction pathway (Whiticar et al., 1986; Sugimoto and Wada, 1993). Previous studies, however, have often reported that acetate fermentation is the major pathway of methanogenesis in profundal lake sediments (Schulz and Conrad, 1996; Schulz et al., 1997; Nozhevnikova et al., 1997). This inconsistency with previous studies might be explained by indirect methane production from $\mathrm{CO}_{2}$ via autotrophic acetogenesis (Nozhevnikova et al., 1997; Hornibrook et al., 2000). Carbon isotope fractionation for acetate production from $\mathrm{H}_{2}$ and $\mathrm{CO}_{2}$ was reported to be compatible with that for the methanogenesis of the $\mathrm{CO}_{2}$ reduction pathway (Gelwicks et al., 1989). When acetate is poor in pore water, both the direct methane production from $\mathrm{CO}_{2}$ reduction pathway $\left(\mathrm{CO}_{2}+8(\mathrm{H}) \rightarrow\right.$ $\mathrm{CH}_{4}+2 \mathrm{H}_{2} \mathrm{O}$ ) and the indirect methane production via homoacetogenesis and acetate fermentation $\left(2 \mathrm{CO}_{2}+8(\mathrm{H}) \rightarrow \mathrm{CH}_{3} \mathrm{COOH}+2 \mathrm{H}_{2} \mathrm{O} \rightarrow\right.$ $\mathrm{CH}_{4}+\mathrm{CO}_{2}+2 \mathrm{H}_{2} \mathrm{O}$ ) would result in similar values of $\delta^{13} \mathrm{C}_{\mathrm{CH}_{4}}$.
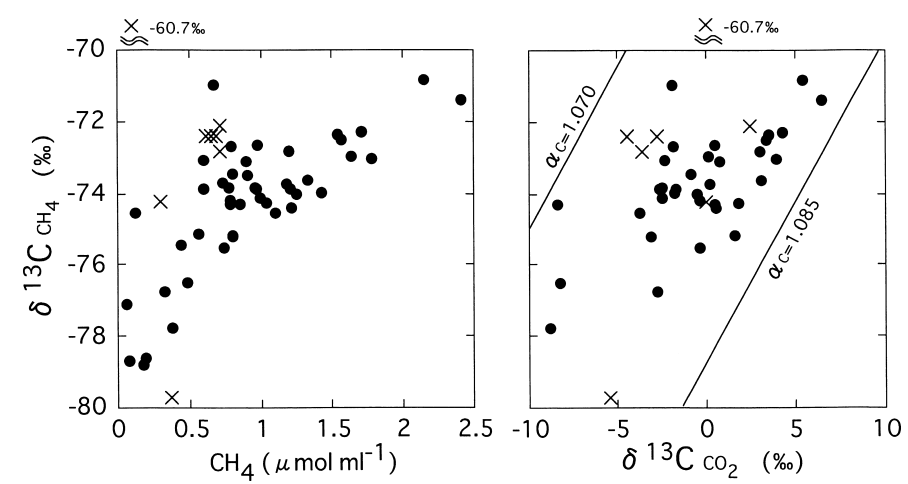

Fig. 4. $\mathrm{\delta}^{13} \mathrm{C}-\mathrm{CH}_{4}$ vs. (a) methane content and (b) $\delta^{13} \mathrm{C}-\Sigma \mathrm{CO}_{2}$ in sediment from the north $(\mathbf{O})$ and south $(\times)$ basins of Lake Biwa. Lines of equal apparent fractionation are drawn for $\mathrm{\alpha cCH}_{4}-\mathrm{CO}_{2}=1.070$ and 1.085. 
Another explanation may be possible by the effect of productivity of freshwater environments on the methane production pathway. Most of studies on methane production in freshwater sediments have been conducted in eutrophic lakes and marshes, where are rich in available organic substrates for methane production. On the other hand, Lake Biwa is categorized into an oligo- to mesotrophic lake. Furthermore, major part of methane production is in the subsurface layer deeper than $6 \mathrm{~cm}$ depth from the surface of the sediment, where the organic matter content is much lower than the surface (Murase and Sugimoto, in press; Murase and Sakamoto, 2000). In anoxic marine sediments, availability of organic substrates for methanogenesis is generally limited by the activity of sulfate reduction especially in the surface part rich in labile organic matters (Zehnder and Stumm, 1988). Oligotrophic lake sediments and marine sediments might be a similar environment in terms of low availability of organic substrates for methanogenesis. Methanogenesis from $\mathrm{CO}_{2}$ reduction pathway is suggested to be relatively more important in decomposition of more extensively degraded or older organic matter in the subsurface sediment (Schoell, 1988). Further study on direct estimation of methanogenic pathway in the lake sediment of Lake Biwa is in progress.

Acknowledgments-We thank Captain B. Kaigai of the R/V Hassaka of the University of Shiga Prefecture for his cooperation during sampling. This research was financially supported by a Grant in Aid (No. 11213208) from the Ministry of Education, Science, Sports, and Culture, Japan. We are also grateful to Prof. E. Wada, project leader of IGBP-MESSC, for his encouragement.

\section{REFERENCES}

Casper, P. (1996) Methane production in littoral and profundal sediments of an oligotrophic and a eutrophic lake. Arch. Hydrobiol. 48, 253-259.

den Heyer, C. and Kalff, J. (1998) Organic matter mineralization rates in sediments: A within- and amonglake study. Limnol. Oceanogr. 43, 695-705.

Gelwicks, J., Risatti, J. B. and Hayes, J. M. (1989) Carbon isotope effects associated with autotrophic acetogenesis. Org. Geochem. 14, 441-446.

Hornibrook, E. R. C., Longstaffe, F. J. and Fyfe, W. S.
(2000) Evolution of stable carbon isotopic compositions for methane and carbon dioxide in freshwater wetlands and other anaerobic environments. Geochim. Cosmochim. Acta 64, 1013-1027.

Lansdown, J. M., Quay, P. D. and King, S. L. (1992) $\mathrm{CH}_{4}$ production via $\mathrm{CO}_{2}$ reduction in a temperate bog: A source of ${ }^{13} \mathrm{C}$-depleted $\mathrm{CH}_{4}$. Geochim. Cosmochim. Acta 56, 3493-3503.

Murase, J. and Sakamoto, M. (2000) Horizontal distribution of carbon and nitrogen and their isotopic compositions in the surface sediment of Lake Biwa. Limnology 1, 177-184.

Murase, J. and Sugimoto, A. (in press) Seasonal and spatial variations of methane production in mesotrophic lake sediments (Lake Biwa, Japan). Verh. Int. Ver. Limnol.

Nozhevnikova, A. N., Holliger, C., Ammann, A. and Zehnder, A. J. B. (1997) Methanogenesis in sediments from deep lakes at different temperatures $\left(2-70^{\circ} \mathrm{C}\right)$. Wat. Sci. Tech. 36, 57-64.

Schoell, M. (1988) Multiple origins of methane in the earth. Chem. Geol. 71, 1-10.

Schulz, S. and Conrad, R. (1996) Influence of temperature on pathways to methane production in the permanently cold profundal sediment of Lake Constance. FEMS Microbiol. Ecol. 20, 1-14.

Schulz, S., Matsuyama, H. and Conrad, R. (1997) Temperature dependence of methane production from different precursors in a profundal sediment (Lake Constance). FEMS Microbiol. Ecol. 22, 207-213.

Sugimoto, A. (1996) GC/GC/C/IRMS system for carbon isotope measurement of low-level methane concentration. Geochem. J. 30, 195-200.

Sugimoto, A. and Wada, E. (1993) Carbon isotopic composition of bacterial methane in a soil incubation experiment: Contributions of acetate and $\mathrm{CO}_{2} / \mathrm{H}_{2}$. Geochim. Cosmochim. Acta 57, 4015-4027.

Whiticar, M. J., Faber, E. and Schoell, M. (1986) Biogenic methane formation in marine and freshwater environments: $\mathrm{CO}_{2}$ reduction vs. acetate fermentation-Isotope evidence. Geochim. Cosmochim. Acta 50, 693-709.

Yoshioka, T., Wada, E. and Saijo, Y. (1988) Isotopic characterization of Lake Kizaki and Lake Suwa. Jpn. J. Limnol. 49, 119-128.

Yoshioka, T., Hayashi, H. and Wada, E. (1989) Seasonal variations of carbon and nitrogen isotope ratios of plankton and sinking particles in Lake Kizaki. Jpn. J. Limnol. 50, 313-320.

Zehnder, A. J. B. and Stumm, W. (1988) Geochemistry and biogeochemistry of anaerobic habitats. Biology of Anaerobic Microorganisms (Zehnder, A. J. B., ed.), 1-38, John Wiley \& Sons.

Zeikus, J. G. and Winfrey, M. R. (1976) Temperature limitation of methanogenesis in aquatic sediments. Appl. Environ. Microbiol. 31, 99-107. 
Appendix. Data of $\mathrm{CH}_{4}$ and $\mathrm{CO}_{2}$ analysis in sediments of Lake Biwa

\begin{tabular}{|c|c|c|c|c|c|c|c|c|c|c|c|}
\hline \multirow[t]{2}{*}{ Date } & \multicolumn{2}{|c|}{ Site } & \multirow{2}{*}{$\begin{array}{l}\text { Water } \\
\text { depth } \\
\text { (m) }\end{array}$} & \multirow[t]{2}{*}{ Rep. } & \multicolumn{2}{|c|}{ Gas concentration } & \multicolumn{2}{|c|}{ Isotopic ratio } & \multicolumn{3}{|c|}{ Data of bulk sediment } \\
\hline & latitude $(\mathrm{N})$ & longitude (E) & & & $\begin{array}{c}\mathrm{CH}_{4} \\
\left(\mu \mathrm{mol} \mathrm{ml}^{-1}\right)\end{array}$ & $\begin{array}{c}\Sigma \mathrm{CO}_{2} \\
\left(\mu \mathrm{mol} \mathrm{ml}^{-1}\right)\end{array}$ & $\begin{array}{c}\delta^{13} \mathrm{C}_{\mathrm{CH}_{4}} \\
(\% 0)\end{array}$ & $\begin{array}{c}\delta^{13} \mathrm{C}_{\mathrm{CO}_{2}} \\
(\% 0)\end{array}$ & $\begin{array}{c}\delta^{15} \mathrm{~N}^{*} \\
(\% 0)\end{array}$ & $\begin{array}{l}\delta^{13} \mathrm{C}^{*} \\
(\% 0)\end{array}$ & $\begin{array}{l}\text { total-C* } \\
\left(\mathrm{mg} \mathrm{g}^{-1}\right)\end{array}$ \\
\hline \multicolumn{12}{|l|}{ North Basin } \\
\hline \multirow[t]{4}{*}{$22 \mathrm{Jul}{ }^{\prime} 97$} & $35^{\circ} 16.97^{\prime}$ & $136^{\circ} 11.64^{\prime}$ & 31 & 1 & 0.18 & 1.26 & -78.8 & n.d. & 4.9 & -25.6 & 25.7 \\
\hline & & & & 2 & 0.20 & 1.04 & -78.6 & n.d. & & & \\
\hline & $35^{\circ} 16.91^{\prime}$ & $136^{\circ} 2.96^{\prime}$ & 42 & 1 & 0.06 & 1.54 & -77.1 & n.d. & 4.6 & -25.2 & 24.6 \\
\hline & & & & 2 & 0.38 & 2.39 & -77.8 & -8.8 & & & \\
\hline \multirow[t]{4}{*}{$23 \mathrm{Jul}$ '97 } & $35^{\circ} 14.10^{\prime}$ & $136^{\circ} 0.76^{\prime}$ & 75 & 1 & 0.56 & 1.66 & -75.1 & n.d. & 6.6 & -25.0 & 33.0 \\
\hline & & & & 2 & 0.44 & 2.13 & -75.4 & n.d. & & & \\
\hline & $35^{\circ} 14.31^{\prime}$ & $136^{\circ} 8.24^{\prime}$ & 24 & 1 & 0.08 & 0.99 & -78.7 & n.d. & 6.0 & -25.2 & 22.6 \\
\hline & & & & 2 & 0.13 & 1.03 & -74.5 & n.d. & & & \\
\hline \multirow[t]{4}{*}{$24 \mathrm{Jul}$ '97 } & $35^{\circ} 9.74^{\prime}$ & $135^{\circ} 57.69^{\prime}$ & 39 & 1 & 0.59 & 2.33 & -73.9 & n.d. & 6.1 & -25.1 & 22.6 \\
\hline & & & & 2 & 0.73 & 3.01 & -73.7 & n.d. & & & \\
\hline & $35^{\circ} 11.60^{\prime}$ & $135^{\circ} 59.22^{\prime}$ & 70 & 1 & 0.91 & 2.59 & -73.5 & n.d. & 7.6 & -25.3 & 35.9 \\
\hline & & & & 2 & 0.77 & 2.58 & -73.8 & n.d. & & & \\
\hline \multirow[t]{4}{*}{28 Jul '97 } & $35^{\circ} 21.89^{\prime}$ & $136^{\circ} 12.41^{\prime}$ & 51 & 1 & 0.80 & 4.27 & -75.2 & -3.1 & 5.7 & -24.8 & 31.3 \\
\hline & & & & 2 & 0.78 & 3.21 & -74.3 & 0.5 & & & \\
\hline & $35^{\circ} 21.68^{\prime}$ & $136^{\circ} 14.03^{\prime}$ & 36 & 1 & 0.90 & 3.42 & -73.1 & 0.8 & 5.9 & -24.9 & 28.9 \\
\hline & & & & 2 & 1.19 & 3.84 & -72.8 & 3.0 & & & \\
\hline \multirow[t]{4}{*}{4 Aug '97 } & $35^{\circ} 19.97^{\prime}$ & $136^{\circ} 6.24^{\prime}$ & 100 & 1 & 0.49 & 2.69 & -76.5 & -8.3 & 6.3 & -24.7 & 28.4 \\
\hline & & & & 2 & 0.85 & 11.2 & -74.3 & -8.4 & & & \\
\hline & $35^{\circ} 21.86^{\prime}$ & $136^{\circ} 6.64^{\prime}$ & 92 & 1 & 1.00 & 4.27 & -74.1 & -2.5 & 7.1 & -25.1 & 29.4 \\
\hline & & & & 2 & 1.21 & 6.34 & -73.9 & -2.6 & & & \\
\hline \multirow[t]{4}{*}{6 Aug '97 } & $35^{\circ} 24.24^{\prime}$ & $136^{\circ} 10.45^{\prime}$ & 53 & 1 & 1.56 & 4.75 & -72.5 & 3.4 & 6.5 & -24.9 & 31.0 \\
\hline & & & & 2 & 1.54 & 4.96 & -72.3 & 3.5 & & & \\
\hline & $35^{\circ} 28.33^{\prime}$ & $136^{\circ} 10.40^{\prime}$ & 40 & 1 & 0.80 & 3.09 & -72.7 & -1.9 & 6.7 & -24.6 & 27.5 \\
\hline & $35^{\circ} 24.27^{\prime}$ & $136^{\circ} 11.59^{\prime}$ & 35 & 1 & 0.98 & 4.23 & -72.6 & 0.5 & 5.2 & -24.8 & 28.4 \\
\hline \multirow[t]{4}{*}{11 Aug '97 } & $35^{\circ} 21.89^{\prime}$ & $136^{\circ} 8.36^{\prime}$ & 92 & 1 & 1.10 & 6.85 & -74.5 & -3.7 & 7.0 & -24.9 & 30.9 \\
\hline & & & & 2 & 1.25 & 4.09 & -74.0 & -0.5 & & & \\
\hline & $35^{\circ} 26.76^{\prime}$ & $136^{\circ} 8.02^{\prime}$ & 51 & 1 & 1.04 & 3.64 & -74.3 & 1.9 & 6.3 & -24.7 & 29.5 \\
\hline & & & & 2 & 1.22 & 4.25 & -74.4 & 0.6 & & & \\
\hline \multirow[t]{3}{*}{27 Feb '98 } & $35^{\circ} 22.05^{\prime}$ & $136^{\circ} 6.79^{\prime}$ & 90 & 1 & 0.80 & 2.33 & -73.4 & -0.8 & 7.6 & -25.0 & 33.4 \\
\hline & & & & 2 & 0.96 & 4.03 & -73.8 & -2.5 & & & \\
\hline & $35^{\circ} 17.75^{\prime}$ & $136^{\circ} 10.32^{\prime}$ & 50 & 1 & 0.32 & 1.58 & -76.8 & -2.8 & 5.8 & -24.8 & 24.3 \\
\hline \multirow[t]{6}{*}{4 Jun '99 } & $35^{\circ} 11.33^{\prime}$ & $135^{\circ} 57.02^{\prime}$ & 64 & 1 & 2.41 & 4.10 & -71.4 & 6.5 & n.d. & n.d. & n.d. \\
\hline & & & & 2 & 1.78 & 3.56 & -73.0 & 4.0 & & & \\
\hline & $35^{\circ} 9.71^{\prime}$ & $135^{\circ} 58.87^{\prime}$ & 21 & 1 & 0.78 & 2.68 & -74.2 & -0.3 & n.d. & n.d. & n.d. \\
\hline & & & & 2 & 0.97 & 8.01 & -73.9 & -1.7 & & & \\
\hline & $35^{\circ} 8.94^{\prime}$ & $135^{\circ} 59.49^{\prime}$ & 12 & 1 & 0.59 & 3.61 & -73.1 & -2.4 & n.d. & n.d. & n.d. \\
\hline & & & & 2 & 0.67 & 3.84 & -71.0 & -1.9 & & & \\
\hline \multirow[t]{8}{*}{12 Jul '99 } & $35^{\circ} 23.05^{\prime}$ & $136^{\circ} 3.18^{\prime}$ & 54 & 1 & 1.71 & 4.52 & -72.3 & 4.3 & 6.2 & -24.9 & 32.0 \\
\hline & & & & 2 & 2.14 & 4.52 & -70.9 & 5.4 & & & \\
\hline & $35^{\circ} 24.16^{\prime}$ & $136^{\circ} 4.96^{\prime}$ & 91 & 1 & 1.43 & 4.15 & -74.0 & -1.8 & n.d. & n.d. & n.d. \\
\hline & & & & 2 & 1.64 & 4.23 & -73.0 & 0.1 & & & \\
\hline & $35^{\circ} 21.54^{\prime}$ & $136^{\circ} 10.33^{\prime}$ & 76 & 1 & 1.18 & 3.78 & -73.7 & 0.2 & n.d. & n.d. & n.d. \\
\hline & & & & 2 & 1.33 & 3.37 & -73.6 & 3.1 & & & \\
\hline & $35^{\circ} 20.53^{\prime}$ & $136^{\circ} 13.51^{\prime}$ & 38 & 1 & 0.74 & 2.93 & -75.5 & -0.3 & n.d. & n.d. & n.d. \\
\hline & & & & 2 & 0.80 & 2.66 & -75.2 & 1.6 & & & \\
\hline
\end{tabular}


Appendix. (continued)

\begin{tabular}{|c|c|c|c|c|c|c|c|c|c|c|c|}
\hline \multirow[t]{2}{*}{ Date } & \multicolumn{2}{|c|}{ Site } & \multirow{2}{*}{$\begin{array}{l}\begin{array}{l}\text { Water } \\
\text { depth }\end{array} \\
\text { (m) }\end{array}$} & \multirow[t]{2}{*}{ Rep. } & \multicolumn{2}{|c|}{ Gas concentration } & \multicolumn{2}{|c|}{ Isotopic ratio } & \multicolumn{3}{|c|}{ Data of bulk sediment } \\
\hline & latitude $(\mathrm{N})$ & longitude (E) & & & $\begin{array}{c}\mathrm{CH}_{4} \\
\left(\mu \mathrm{mol} \mathrm{ml}^{-1}\right)\end{array}$ & $\begin{array}{c}\Sigma \mathrm{CO}_{2} \\
\left(\mu \mathrm{mol} \mathrm{ml}^{-1}\right)\end{array}$ & $\begin{array}{c}\delta^{13} \mathrm{C}_{\mathrm{CH}_{4}} \\
(\% o)\end{array}$ & $\begin{array}{c}\delta^{13} \mathrm{C}_{\mathrm{CO}_{2}} \\
(\% 0)\end{array}$ & $\begin{array}{c}\delta^{15} \mathrm{~N}^{*} \\
(\% 0)\end{array}$ & $\begin{array}{l}\delta^{13} \mathrm{C}^{*} \\
(\% o)\end{array}$ & $\begin{array}{l}\text { total-C* } \\
\left(\mathrm{mg} \mathrm{g}^{-1}\right)\end{array}$ \\
\hline \multicolumn{12}{|l|}{ South Basin } \\
\hline \multirow[t]{8}{*}{21 May '99 } & $35^{\circ} 3.35^{\prime}$ & $135^{\circ} 53.40^{\prime}$ & 4.0 & 1 & 0.71 & 4.71 & -72.8 & -3.6 & n.d. & n.d. & n.d. \\
\hline & & & & 2 & 0.65 & 4.56 & -72.4 & n.d. & & & \\
\hline & $35^{\circ} 3.29^{\prime}$ & $135^{\circ} 53.40^{\prime}$ & 4.5 & 1 & 0.62 & 4.89 & -72.4 & -4.5 & n.d. & n.d. & n.d. \\
\hline & & & & 2 & 0.68 & 4.84 & -72.4 & -2.8 & & & \\
\hline & $35^{\circ} 2.81^{\prime}$ & $135^{\circ} 54.37^{\prime}$ & 3.6 & 1 & 0.37 & 7.23 & -79.7 & -5.4 & n.d. & n.d. & n.d. \\
\hline & & & & 2 & 0.30 & 27.9 & -74.2 & 0.0 & & & \\
\hline & $35^{\circ} 2.79^{\prime}$ & $135^{\circ} 54.69^{\prime}$ & 3.0 & 1 & 0.71 & 12.4 & -72.1 & 2.5 & n.d. & n.d. & n.d. \\
\hline & & & & 2 & 0.04 & 19.9 & -60.7 & -0.6 & & & \\
\hline
\end{tabular}

*Data of bulk sediment are taken from Murase and Sakamoto (2000). n.d.: No data. 